\title{
THE EFFECT OF LOCAL HEATING ON THE FLOW AND COMPOSITION OF RETE TESTIS FLUID IN THE CONSCIOUS RAM
}

\author{
B. P. SETGHELL, ${ }^{*}$ J. K. VOGLMAYR $\dagger$ AND N. T. HINKS \\ CSIRO Division of Animal Physiology, Ian Clunies Ross Animal \\ Research Laboratory, Prospect, N.S.W. 2149, Australia, and \\ $\dagger$ Department of Veterinary Physiology, University of Sydney, \\ N.S.W. 2006, Australia
}

(Received 18th March 1970)

\begin{abstract}
Summary. Fluid was collected from the cannulated rete testis of six conscious Merino rams whose testes were heated to $40.5^{\circ} \mathrm{C}$ for $3 \mathrm{hr}$. Rate of fluid flow dropped during heating but recovered thereafter; there were 100- to 10,000-fold decreases in sperm concentration which appeared to be biphasic. The timing supported the suggestion that heating had affected pachytene spermatocytes and division of type-B spermatogonia.

The concentration of sodium, potassium, lactic acid, chloride, protein and testosterone in the fluid was unrelated to the number of spermatozoa present but above $20 \times 10^{6}$ spermatozoa/ml the concentration of inositol and glutamic acid appeared to be positively correlated with sperm number. Below this sperm concentration, small amounts of glucose appeared in some samples of fluid.

The results clearly indicate that the secretion of rete testis fluid can be independent of the release of spermatozoa from the germinal epithelium.
\end{abstract}

\section{INTRODUCTION}

The damaging effect of heat on the testis has been known for many years (see Waites \& Setchell, 1969, for references) and more recently, precise stages of spermatogenesis in the ram have been shown to be sensitive to heat (Waites \& Ortavant, 1968). No studies have been made of the effects of heat on the transport of the formed but immature spermatozoa from the testis into the epididymis. This transport which must be regarded as an essential step in sperm production, is probably achieved by the secretion in the seminiferous tubules of fluid which flows through the rete testis and the efferent ducts to be reabsorbed in the epididymis (Voglmayr, Waites \& Setchell, 1966; Voglmayr, Scott, Setchell \& Waites, 1967; Setchell, Scott, Voglmayr \& Waites, 1969). It was, therefore, of interest to determine whether changes in the numbers of spermatozoa liberated by the testis after heating were associated with changes in the production of this fluid and in its composition.

* Present address: Institute of Animal Physiology, Babraham, Cambridge, England. 


\section{MATERIALS AND METHODS}

\section{Animals}

Cannulae were implanted in the rete testis of six Merino rams, 2 to 3 years old and weighing between 48 and $59 \mathrm{~kg}$, which were fed and kept in a controlled environment, as described by Voglmayr et al. (1967).

In four rams (Nos. 2, 3,5 and 6), rete testis fluid was collected daily during a control period of between 5 and 10 days, after which the testes were heated for $3 \mathrm{hr}$ by immersing the scrotum in water at $40.5^{\circ} \mathrm{G}$ in a container, as described by Waites \& Setchell (1964). Fluid collection was continued during heating
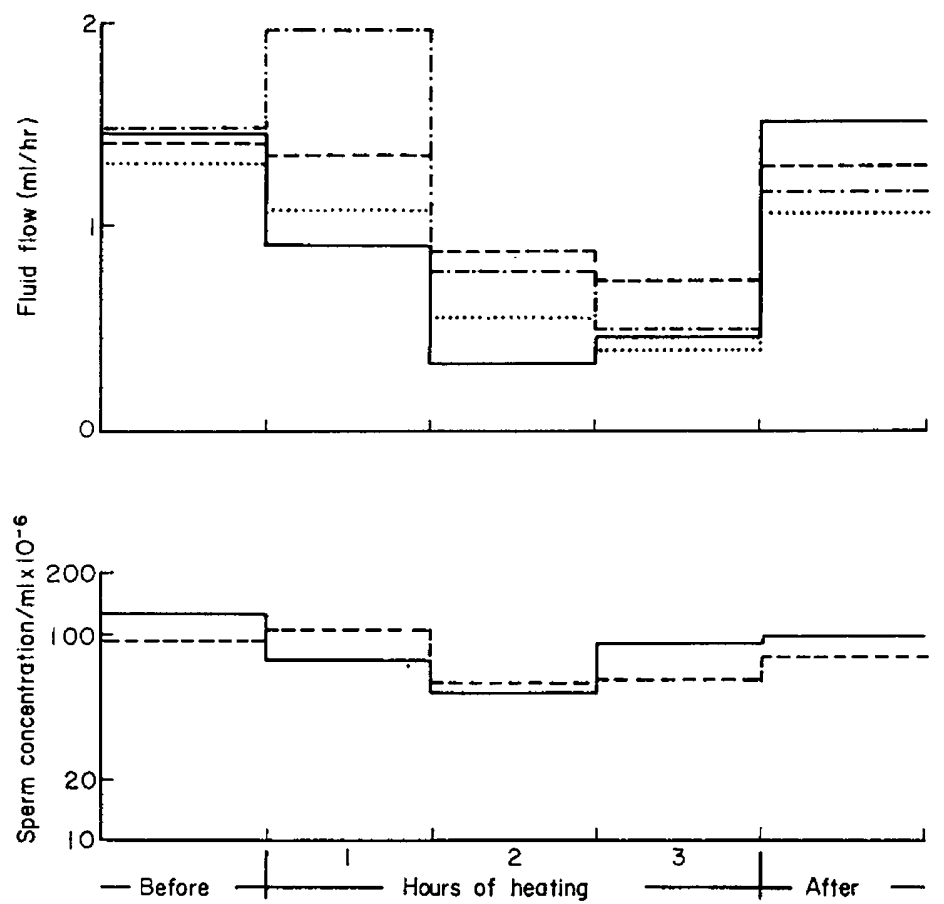

TEXT-FIG. 1. Rete testis fluid production and sperm concentration in rete testis fluid before, during and after locally heating the testis to $40.5^{\circ} \mathrm{C}$ for $3 \mathrm{hr}$. - Ram 2; -.--, Ram $3 ;-\cdot-.--$, , Ram $5 ; \cdots \cdots$, Ram 6.

and thereafter for as long as the catheter remained patent. In two of the rams (5 and 6) shown in Text-fig. 1, the catheters became blocked before there were any significant changes in sperm concentration and therefore, except for the changes seen during heating, the results from these animals have not been included. When the catheter became blocked in two other rams (2 and 3) during the period in which sperm concentration was decreasing, the rams were anaesthetized and the testis was removed. The remaining testis was cannulated at the times shown in Text-fig. 2 (centre two panels) and collections restarted. Collections were made from another ram (4) for 10 days and this testis was removed when the catheter became blocked; the other testis was 
heated 35 days later and collections began 21 days after the heating, i.e. at about the time when the fall in concentration of spermatozoa would be expected, to try to avoid the catheter blocking during the time when sperm

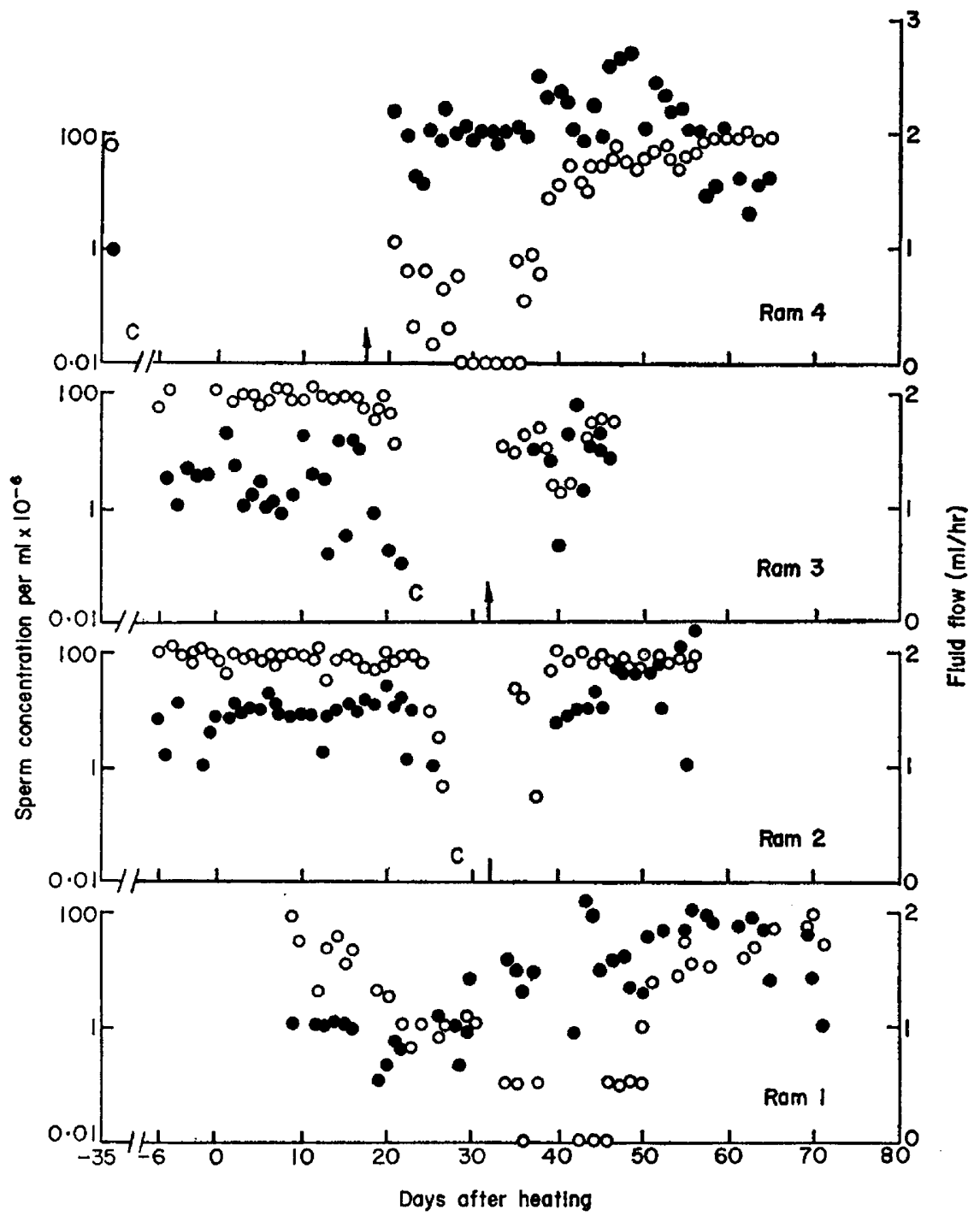

Text-FIG. 2. Rete testis fluid production (e) and the concentration (on a logarithmic scale) of spermatozoa in the rete testis fluid (O) of four rams before and after heating the testis or testes to $40.5^{\circ} \mathrm{C}$ for $3 \mathrm{hr}$ on Day 0 (rams 2 to 4 ) or by insulating the scrotum in a plastic bag between Day -1 and +1 (ram 1). The single value given for ram 4 at Day -35 is a mean of ten measurements made on successive days between 45 and 35 days before heating. $\mathrm{C}$ : cannulated testis removed surgically. $\uparrow:$ other rete testis cannulated.

concentration was falling. The testes of another ram (1) were heated by enclosing its scrotum in a polythene bag for 3 days and collections of rete testis fluid began 9 days after heating. Collections were made for $24 \mathrm{hr}$ or for 8 and 
$16 \mathrm{hr}$, alternately. There were no differences in the amount or composition of the fluid due to the different collection periods.

\section{Analytical techniques}

Spermatozoa in rete testis fluid, diluted with $1 \%$ formalin in physiological saline if necessary, were counted in a haematocytometer immediately after removing the polyethylene collecting receptacle from the animal. The rest of the fluid was then centrifuged ( $2000 \mathrm{~g}$ for $20 \mathrm{~min}$ ) and the cell-free fluid stored frozen until analysed. Sodium and potassium were measured with an automated flame photometer (Autoanalyser, Technicon, Chauncey, New York), chloride with a coulometric titrator (Evans Electroselenium, Halstead, Essex), glucose by the method of Washko \& Rice (1961), glutamate by the method of Sowerby \& Ottaway (1966), protein by the biuret method and lactate by the method of Lundholm, Mohme-Lundholm \& Vamos (1963).

Inositol was determined after paper chromatography of $20 \mu \mathrm{l}$ of rete testis fluid with isopropanol-ammonia-water $(7: 1: 2$ by vol) by eluting the area corresponding to inositol and measuring the inositol by periodate oxidation (Gaitonde \& Griffiths, 1966). Testosterone was determined directly on $0.1 \mathrm{ml}$ fluid by a modification by Hinks, Setchell \& Linzell (in preparation) of the protein-binding method of Kato \& Horton (1968).

\section{RESULTS}

Flow of rete testis fuid and the concentration of spermatozoa during heating

Measurements in four rams showed that flow of rete testis fluid fell when the scrotum was heated but recovered to pre-treatment values immediately afterwards (Text-fig. 1). The fall was most noticeable in the 2nd and 3rd hours of heating when the fluid flow was only about one quarter of the pre- and posttreatment values. The concentration of spermatozoa in the fluid did not change consistently during heating in the two rams in which this was measured.

\section{Flow of rete testis fuid and the concentration of spermatozoa after heating}

Once the flow of fluid had recovered after heating, there were only random fluctuations in the rate of flow, despite 10,000-fold changes in the concentration of spermatozoa. The concentration of spermatozoa began to fall about 20 days after heating. In two rams, the fall in concentration occurred just before the catheter became blocked but it is unlikely that this would have caused an artifact for two reasons; first, our experience would lead us to expect either no change or a rise in concentration before blockage and second, a considerable number of agglutinated multinucleated cells appeared in the fluid as the number of spermatozoa decreased. These cells could well have blocked the catheter and probably came from the damaged germinal epithelium.

Despite the difficulties in maintaining the catheters at this critical time, it would appear that the fall in concentration of spermatozoa was biphasic; the initial fall was at about 20 days and a secondary one occurred at between 29 and 37 days. In the ram (4) which was recannulated as the sperm concentration was falling, and in the ram (1) whose testis was heated by insulation, the biphasic 

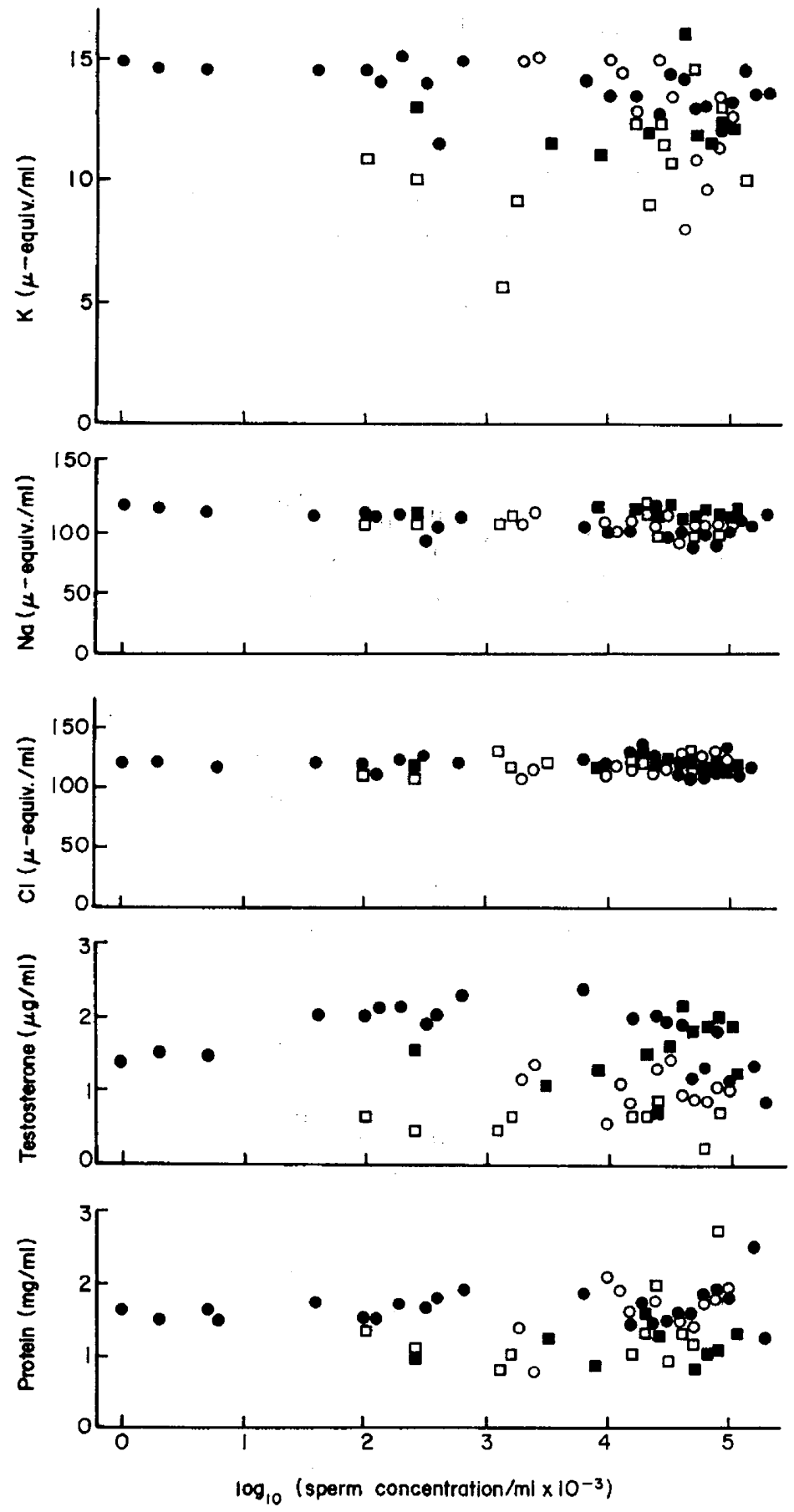

TExT-FIG. 3. The concentrations of potassium, sodium, chloride, testosterone and protein plotted against the concentration of spermatozoa in rete testis fluid: $\square, \operatorname{ram} 1$; $0, \operatorname{ram} 2$; 0 , ram $3 ; 0$, ram 4 . Each point is the mean of the values for all the samples with a $\log _{10}$ concentration between the value plotted and a value 0.1 greater, i.e. the point plotted against 5.0 represents the mean of all samples with $\log _{10}$ sperm concentrations between 5.0 and $5 \cdot 1$. The number of samples to each point ranged between 1 and 15 . 
fall could be seen more clearly and lower sperm concentrations were seen during the second phase of the fall (Text-fig. 2).

\section{Composition of rete testis fluid after heating}

Despite the fluctuations in the concentration of spermatozoa in the rete testis fluid after heating, there were only minor changes in the concentrations of the other substances examined. Neither sodium nor chloride concentrations bore any relation to the concentration of spermatozoa. There was a suggestion in one ram that potassium concentration decreased when the numbers of spermatozoa
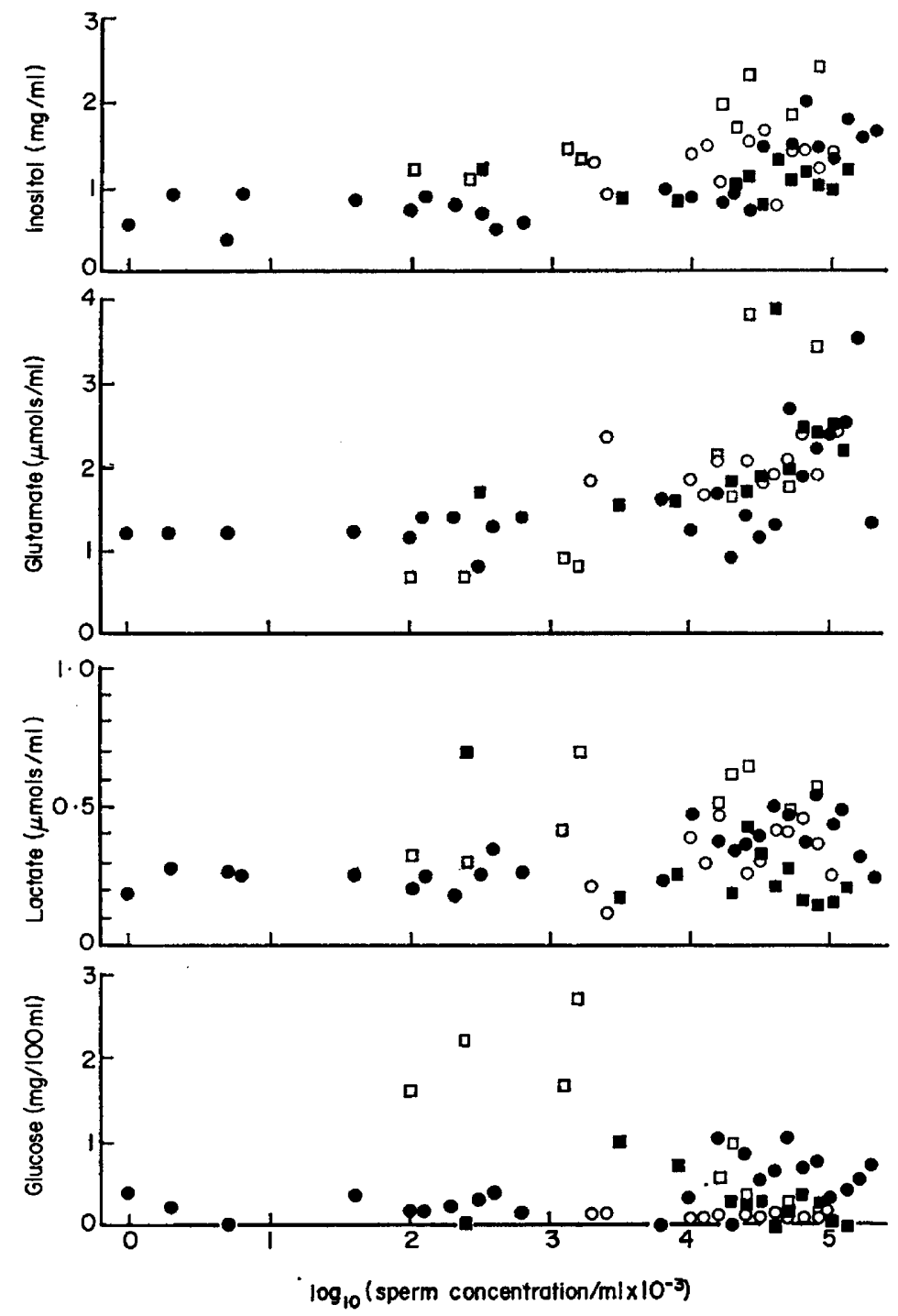

TEXT-FIG. 4. The concentrations of glucose, lactate, glutamate and inositol plotted against the concentration of spermatozoa in rete testis fluid. Calculation and symbols as for Text-fig. 3. 
fell below $20 \times 10^{6} / \mathrm{ml}$ (Text-fig. 3). In this ram also, the concentration of glucose rose when the sperm concentration was less than $20 \times 10^{6} / \mathrm{ml}$. However, these findings were not substantiated in the other rams in which there was little relation between sperm density and the concentration of either glucose or potassium. The concentration of lactate was rather variable and unrelated to the number of spermatozoa present.

In contrast to these findings, the concentration of inositol and glutamate appeared to be positively correlated with sperm numbers in three of the four rams $(\mathrm{r}=0.781 * * *(9$ d.f. $), 0.350 *(49),-0.027(29), 0.514 * * *(39)$ for inositol and $0.709 * * *, 0.337 *, 0.125,0.551^{* * *}$ for glutamate for rams 1 to 4 respectively). Below a concentration of about $10 \times 10^{6}$ spermatozoa $/ \mathrm{ml}$, the concentrations of inositol and glutamate remained at about $1 \mathrm{mg} / \mathrm{ml}$ and $1 \mu \mathrm{mol} / \mathrm{ml}$, values still considerably in excess of those in plasma (Text-fig. 4).

Testosterone and protein were present in similar concentrations in fluids with high and low concentrations of spermatozoa (Text-fig. 3).

\section{DISGUSSION}

The secretion of rete testis fluid appears to be largely independent of the release of spermatozoa because, after local heating, similar volumes of fluid were secreted despite large changes in the concentrations of spermatozoa. This emphasizes that the testis has an exocrine function as well as its spermatogenic and endocrine rôles, and agrees with evidence from immature animals in which fluid secretion precedes the liberation of the first spermatozoa (Setchell, 1970).

The specificity of fluid secretion is further stressed by the persistence of its characteristic chemical composition in the face of widely varying concentrations of spermatozoa. Confirming the earlier observations (Voglmayr eta l., 1966; Setchell, Hinks, Voglmayr \& Scott, 1967; Setchell, Dawson \& White, 1968), the concentration of sodium is about 0.9 times that of plasma, chloride about 1.20 times, potassium about 3 times, glutamate about 8 times and inositol about 80 times that of plasma; glucose is practically absent from rete testis fluid, protein concentration is very low but testosterone is present in concentrations about half those found in plasma from the internal spermatic vein or in testicular lymph (see Setchell, Scott, Voglmayr \& Waites, 1969). It is interesting that glutamate and inositol, the only compounds whose concentrations were correlated with sperm concentration, are both synthesized by testicular spermatozoa from glucose (Setchell et al., 1967; Voglmayr \& White, 1971).

The concentration differences between rete testis fluid and blood plasma have been advanced as part of the evidence for active secretion of this fluid rather than passive filtration (Setchell, Scott, Voglmayr \& Waites, 1969) and the fall in fluid secretion during heating is further evidence for an active process. Because the metabolic rate of the testis increases with temperature but its blood flow does not, it has been suggested that the heated testis is hypoxic (Waites \& Setchell, 1964) and it is interesting that hypoxia depressed fluid secretion by the testis in vivo and by the isolated perfused testis (Setchell \& Linzell, 1968; Linzell \& Setchell, 1969). Nothing has apparently been written on the effects of temperature on the active secretion of other fluids such as cerebrospinal fluid 
and aqueous humour, or the active resorption of the primary secretion of the acini of the salivary glands or of glomerular filtrate, but it might be expected that these active processes would be temperature dependent. There is some earlier evidence which suggested that the secretion of rete testis fluid was reduced by increased temperature; the exclusion of [ $\left.{ }^{86} \mathrm{Rb}\right]$ - relative to $\left[{ }^{131} \mathrm{I}\right]$ iodoantipyrine was greater in rat testes while they were locally heated to $37^{\circ} \mathrm{C}$ or $40^{\circ} \mathrm{C}$ (Setchell, Voglmayr \& Waites, 1969). However, rat testes returned to the abdomen at the time of efferent duct ligation secrete normal amounts of fluid (Setchell, 1970) and the acute effects of increased temperature on fluid secretion need further investigation.

The times at which the numbers of testicular spermatozoa produced by the testis were reduced after heating cannot be stated with precision because of the small numbers of experiments and the gaps in the series of observations. There is the added complication that, during the experiment, three of the rams were unilaterally castrated, which might be expected to affect the production of spermatozoa. However, in two rams (2 and 3$)$, the observations were concluded before any alteration in the production of spermatozoa would be expected and in the other, the second period of observations was not begun until 55 days after unilateral castration when the production of spermatozoa would have reached its new level (Voglmayr \& Mattner, 1968; Voglmayr \& Setchell, unpublished observations). From the known time sequence of spermatogenesis in sheep (Ortavant, 1959) and the observations on the cytological effects of a heat treatment similar to that applied here (Waites \& Ortavant, 1968), it is possible to predict when falls in the output of testicular spermatozoa should appear. The destruction of pachytene spermatocytes at late stage 7 or early stage 8 would reduce the output of spermatozoa 20 to 23 days later and the abortive spermatogonial divisions after heat should cause a second reduction after about 30 to 38 days. These calculated values are similar to those observed in the present experiment. The major effect seen by Waites \& Ortavant (1968) was the abortive division of the type-B spermatogonia, which is consistent with the secondary fall in sperm concentration being greater than the initial fall. The marginal losses in spermatids described by Waites \& Ortavant (1968) were not reflected in any changes in the output of spermatozoa up to 20 days after heating, but it is apparent from the higher percentage of abnormal spermatozoa seen in semen before the fall in sperm concentration and the fact that the number of spermatozoa in ejaculates falls as early as 11 days after heating (Waites \& Setchell, 1964) that more subtle damage is done to later stages of spermatogenesis. Allowing for the time spent in the epididymis (Ortavant, 1959), the affected spermatozoa would be those leaving the testis in normal numbers just after heating. It is therefore important to keep in mind that, although the spermatozoa were present in normal numbers in rete testis fluid for 20 days after heating, their metabolism was already deranged (Voglmayr, Setchell \& White, 1971).

\section{REFERENGES}

Gattonde, M. K. \& GRIffiths, M. (1966) A spectrophotometric method for the determination of microquantities of free inositol in biological material. Analyt. Biochem. 15, 532. 
Kato, T. \& Horton, R. (1968) A rapid method for the estimation of testosterone in female plasma. Steroids, 12, 631 .

Linzell, J. L. \& Setchell, B. P. (1969) Metabolism, sperm and fluid production of the isolated perfused testis of the sheep and goat. F. Physiol., Lond. 201, 129.

Lundholm, L., Mohme-Lundholm, E. \& Vamos, N. (1963) Lactic acid assay with $\mathrm{L}(+)$ lactic acid dehydrogenase from rabbit muscle. Acta physiol. scand. 58, 243.

Ortavant, R. (1959) Spermatogenesis and morphology of the spermatozoon. In: Reproduction in Domestic Animals, Vol. II, pp. 1-50. Eds. H. H. Cole and P. T. Cupps. Academic Press, New York.

Setchell, B. P. (1970) The secretion of fluid by the testes of rats, rams and goats, with some observations on the effect of age, cryptorchidism and hypophysectomy. F. Reprod. Fert. 23, 79.

Setchell, B. P., Dawson, R. M. C. \& White, R. W. (1968) The high concentration of free myoinositol in rete testis fluid from rams. J. Reprod. Fert. 17, 219.

Setchell, B. P., Hinks, N. T., Voglmayr, J. K. \& Scott, T. W. (1967) Amino acids in ram testicular fluid and semen and their metabolism by spermatozoa. Biochem. F. 105, 1061.

Setchell, B. P. \& Linzell, J. L. (1968) The effect of some drugs, hormones and physiological factors on the flow of rete testis fluid in the ram. F. Reprod. Fert. 16, 320.

Setcheli, B. P., Scott, T. W., Vogzmayr, J. K. \& Waites, G. M. H. (1969) Characteristics of testicular spermatozoa and the fluid which transports them into the epididymis. Biol. Reprod. Suppl. 1, 40.

Setchell, B. P., Voglmayr, J. K. \& Wattes, G. M. H. (1969) A blood testis barrier restricting passage from blood into rete testis fluid but not into lymph. F. Physiol., Lond. 200, 73.

SOWERBy, J. M. \& OtTAWAy, J. H. (1966) The enzymic estimation of glutamate and glutamine. Biochem. 7. 99, 246.

VoGLMAYR, J. K. \& MATTNeR, P. E. (1968) Compensatory hypertrophy in the remaining testis following unilateral orchidectomy in the adult ram. 7. Reprod. Fert. 17, 179.

Voglmayr, J. K., Scott, T. W., Setchell, B. P. \& Waites, G. M. H. (1967) Metabolism of testicular spermatozoa and characteristics of testicular fluid collected from rams. F. Reprod. Fert. 14, 87.

Voglmayr, J. K., Setcheld, B. P. \& White, I. G. (1971) The effects of heat on the metabolism and ultrastructure of ram testicular spermatozoa. F. Reprod. Fert. 24, 71.

Voglmayr, J. K., Waites, G. M. H. \& Setchell, B. P. (1966) Studies on spermatozoa and fluid collected directly from the testis of the conscious ram. Nature, Lond. 210, 861.

Voglmayr, J. K. \& White, I. G. (1971) Synthesis and metabolism of myoinositol in testicular and ejaculated spermatozoa of the ram. F. Reprod. Fert. 24, 29.

Wattes, G. M. H. \& Ortavant, R. (1968) Effets précoces d'une brève élévation de la température testiculaire sur la spermatogenèse du bélier. Annls Biol. anim. Biochim. Biophys. 8, 323.

Wartes, G. M. H. \& Setchell, B. P. (1964) Effect of local heating on blood flow and metabolism in the testis of the conscious ram. J. Reprod. Fert. 8, 339.

Wattes, G. M. H. \& Setchell, B. P. (1969) Some physiological aspects of the function of the testis. In: The Gonads. Ed. K. W. McKerns. Appleton, New York.

Washro, M. E. \& Rice, E. W. (1961) Determination of glucose by an improved enzymatic procedure. Clin. Chem. 7, 542 . 